\title{
Angiotensinogen Measurement
}

National Cancer Institute

\section{Source}

National Cancer Institute. Angiotensinogen Measurement. NCI Thesaurus. Code C74846.

The determination of the amount of ang iotensinogen hormone present in a sample. 